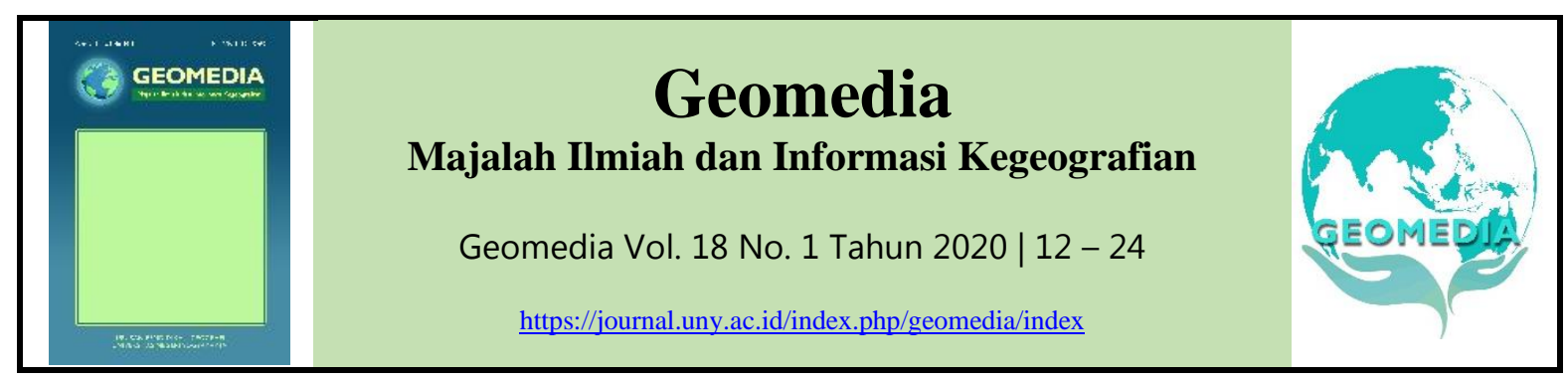

\title{
Analisis Daya Dukung Lingkungan Berbasis Jasa Ekosistem Penyediaan Pangan dan Air Bersih di Kabupaten Semarang
}

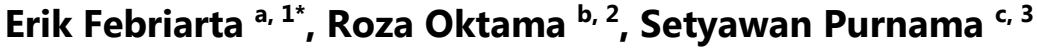 \\ a Fakultas Teknologi Sumber Daya Alam, Institut Teknologi Yogyakarta \\ b Program Studi Ilmu Lingkungan, Pasca Sarjana, Universitas Gadjah Mada, Yogyakarta \\ c Fakultas Geografi, Universitas Gadjah Mada, Yogyakarta \\ ${ }^{1}$ email penulis pertama*; email penulis kedua; email penulis ketiga \\ *korespondensi penulis
}

\begin{tabular}{ll}
\hline \multicolumn{2}{l}{ Informasi artikel } \\
\hline Sejarah artikel & \\
Diterima & $: 11$ Maret 2020 \\
Revisi & $: 18$ Mei 2020 \\
Dipublikasikan & $: 31$ Mei 2020 \\
\hline
\end{tabular}

\section{Kata kunci:}

Daya dukung

Daya tampung

Jasa ekosistem

Penyediaan pangan

Air bersih

\begin{abstract}
A B S T R A K
Kemampuan lingkungan menopang aktivitas kehidupan manusia secara fisik mempunyai batasan. Untuk menjaga sumberdaya alam secara menyeluruh dan berkelanjutan salah satunya dengan invetarisasi daya dukung dan daya tampung. Tujuan dari penelitian ini adalah untuk mengetahui daya dukung dan daya tampung lingkungan dengan pendekatan jasa ekosistem dalam sektor penyediaan yaitu pangan dan air bersih di Kabupaen Semarang. Teknik analisis yang digunkan antara lain pairwise comparation dengan nilai Indek Komposit Jasa Ekosistem (IKJE). Berdasarkan hasil penelitian dikethui penyedia pangan yang mempunyai nilai tinggi berada di bagian timur antara lain Kecamatan Bringin, Bergas, Pringapus dan Suruh. Sedangkan nilai rendah berada di bagian barat. Pola penyedia air bersih juga memiliki pola yang sama secara umum berada di bagian timur yang tinggi, hal tersebut dipengaruhi oleh kondisi lingkungan fisik. Sebagian besar lahan yang memiliki kelas tinggi dalam jasa penyediaan pangan terletak pada Ekoregion Kaki Gunungapi, Lereng Kaki Gunungapi, Dataran Fluvio-vulkan
\end{abstract}

Keywords:
Carrying capacity
Environmental capacity
Ecosystem service
Food supply
Clean water

\section{Keywords:}

Carrying capacity

capacity

Food supply

Clean water

\section{A B S T R A C T}

The environment has limited physical abilities to sustain the activities of human life. Inventories of carrying capacity and environmental capacity are thereby suggested so as to maintain natural resources altogether and sustainably. This study was designed to determine carrying and environmental capacities in the supply sector, namely, food and clean water, in Semarang Regency using ecosystem services as the approach. Through pairwise comparison with the Ecosystem Services Composite Index (ESCI), food supply was found to be categorically high in the east, including Bringin, Bergas, Pringapus, and Suruh Districts, and low in the west. Due to the physical environmental conditions, the same pattern generally applied to the clean water supply, which was high in the east. The majority of land supplying a high quantity of food lies in the Volcanic Foot, Volcanic Foot Slope, and Fluvio-Volcanic Plain Ecoregions. 


\section{Pendahuluan}

Lingkungan mempunyai fungsi untuk menopang aktivitas manusia dan makhluk hidup disekitarnya. Kemampuan tersebut merupakan salah satu parameter dalam daya dukung lingkungan untuk mendapatkan kesetimbangan lingkungan. Peningkatan dari pertumbuhan penduduk berdampak kepada peningkatan penggunaan sumberdaya alam, diantaraya pemanfaatan ruang bagi aktivitas kehidupan manusia dan makhluk hidup lainnya. Dampak dari hal tersebut dapat mengakibatkan kualitas dan kuantitas lingkungan di Kabupaten Semarang mengalami penurunan.

Pertumbuhan kegiatan ekonomi dan laju pembangunan diberbagai sektor dalam rangka untuk memenuhi kebutuhan makhluk hidup, mempunyai dampak kondisi lingkungan hidup (Sumadyanti, Zuharnaen, \& Widayani, 2016; Widodo, Lupyanto, Sulistiono, Harjito \& hamidin, 2015). Dampak terhadap lingkungan dapat diindikasikan dengan penurunan kualitas lingkungan dari pemanfaatan sumber daya alam yang semakin meningkat dari akibat semakin meningkatnya aktivitas dari berbagai kegiatan manusia, termasuk pemanfaatan ruang bagi kehidupan manusia dan makhluk hidup. Sedangkan laju pertumbuhan dan perkembangan penduduk berjalan mengikuti kapasitas lingkungan yang memiliki keterbatasan (MEA 2005).

Undang-Undang Pengelolaan Lingkungan Hidup Nomor 32 Tahun 2009 Tentang Pengelolaan Lingkungan Hidup menjadi dasar pertimbangan perencanaan. Selain itu juga di dalam Pasal 20, 23 dan 25 UU Nomor 26 Tahun 2007 menyiratkan bahwa, penyusunan tata ruang wilayah Nasional/Provinsi/Kabupaten/Kota harus mempertimbangkan daya dukung dan daya tampung lingkungan hidup. Keterbatasan lingkungan untuk diolah dan dimanfaatkan untuk menopang aktivitas diatasnya secara kuantitas maupun kualitas dalam waktu yang lama akan menunjukkan penurunan. Untuk mengatasi hal tersebut maka perlunya pemanfaatan sumber daya alam harus digunakan dengan bijaksana dengan mempertimbangkan aspek kemampuan daya dukung dan daya tampung (Muta'ali, 2015).
Pengelolaan sumber daya alam berkelanjutan harus mempertimbangkan keseimbangan antara pemenuhan kebutuhan manusia dengan memperhatiakan kesejahteraan kehidupan sosial, ekonomi dan kelestarian fungsi lingkungan hidup hingga masa datang dengan berkelanjutan (Sabila, 2020). Potensi atau kemampuan lingkungan hidup dalam rangka mendukung dan menopang kehidupan manusia, makhluk hidup lainnya dan kesimbangan diantaranya (daya dukung) serta kemampuan memberikan manfaat dari lingkungan untuk menyerap zat, energi atau komponen lain (daya tampung lingkungan hidup) perlu dipahami dan dijadikan dasar dalam perencanaan pemanfaatan suatu sumber daya alam, perencanaan pembangunan dan perencanaan pemanfaatan ruang dan tata ruang untuk mewujudkan pembangunan yang berkelanjutan (P3ES, 2011; P3EJ, 2017; DLH Kabupaten Semarang, 2018)

Identifikasi dan analisis daya dukung dan daya tampung mempunyai pendekatan dimana bila semakin tinggi nilai jasa ekosistem,semakin tinggi kemampuan daya dukung dan daya tampung lingkungan (MEA, 2005; P3EJ 2017). Pendekatan penilaian jasa eksositem merupakan suatu habitat yang ditentukan oleh faktor endogen (dalam bumi) dan dinamika faktor eksogen yang dicirikan dengan komponen ekoregion dan penutup lahan (land cover/land use) sebagai penaksir nilai (Muta'ali, 2015). Pendekatan yang digunakan dalam jasa ekosistem menggunakan pengolahan data dasar lingkungan diantatranya adalah: (a) daya dukung lingkungan, (b) daya tampung lingkungan, (c) ekoregion (lingkungan yang homogen), (d) penutup lahan dan (e) jasa ekosistem (manfaat yang diperoleh dari manusia). Jasa ekosistem dikategorikan menjadi empat kategori yaitu (a) jasa penyediaan (provisioning), (b) jasa pengaturan (regulating), (c) jasa budaya (cultural), dan jasa pendamping (supporting) (MEA, 2005).

Pendekatan data ekoregion dan data penggunaan lahan merupakan data dasar untuk mengolah parameter jasa ekosistem (P3EJ, 2017). Kabupaten Semarang mempunyai kenampakan topografi beragam diantaranya lereng gunungapi, pergunungan, lembah dan lipatan. Kabupaten 
Semarang dilihat dari proses geomorfologis terdiri atas unit bentuk lahan atau disebut dengan ekoregion yang dikontrol oleh beberapa proses. Proses geomorfologi yang bentuk lahannya terdapat di Kabupaten Semarang antara lain proses struktural, proses vulkanik, dan proses fluvial. Masing-masing unit bentuk lahan tersebut tersebar di wilayah Kabupaten Semarang dengan proporsi tersendiri. Ekoregion berupa Perbukitan Struktural Lipatan Kendeng Batugamping Napalan mendominasi luasan wilayah Kabupaten semarang dengan luas 42958,37 Ha atau sebesar $42,20 \%$. Satuan unit ekoregion yang dikontrol oleh proses gunungapi (vulkanik) memiliki rata-rata luasan $200 \mathrm{Ha}-17664,62 \mathrm{Ha}$ atau setara dengan 0,2\%-17,3\%. Ekoregion dengan luasan paling kecil yang dijumpai di Kabupaten Semarang berupa Dataran Fluvio-vulkan Material Piroklastik dengan luasan 30,25 $\mathrm{Ha}$ atau setara 0,029\% dari luas keseluruhan kabupaten Semarang (Gambar 1).

Selain ekoregion unit analisis penutup lahan memiliki kedudukan tersendiri yang penting untuk diperhatikan. Penutup lahan menjadi ciri dari indikator potensi dari setiap jenis jasa ekosistem (Santosa, 2010). Dikaitkan dengan ekoregion, penutup lahan menjadi fitur permukaan (surface feature) yang kemudian menjadi unit analisis utama dalam kajian daya dukung dan daya tampung lingkungan (Santosa, 2010; Muta'ali, 2015). Berdasarkan luasan masing-masing penutup lahan, Kabupaten Semarang memiliki karakteristik tersendiri. Penutup lahan berupa sawah padi, baik sawah terus menerus maupun sawah dengan selingan tanaman lain memiliki luasan tertinggi, yaitu sebesar $25.730 \mathrm{Ha}$ atau setara $25,2 \%$ dari luasan total. Penutup lahan berupa kebun campuran juga dapat dikatakan mendominasi luasan Kabupaten Semarang, dengan luasan sebesar $21.911 \mathrm{Ha}$ atau seluas 21,5\% dari luas keseluruhan Kabupaten Semarang. Penutup lahan berupa bangunan permukiman desa juga dapat dijumpai dominan di Kabupaten Semarang, dengan luasan mencapai $15.288 \mathrm{Ha}$ atau setara dengan $15,02 \%$ dari luasan total (Gambar 2).

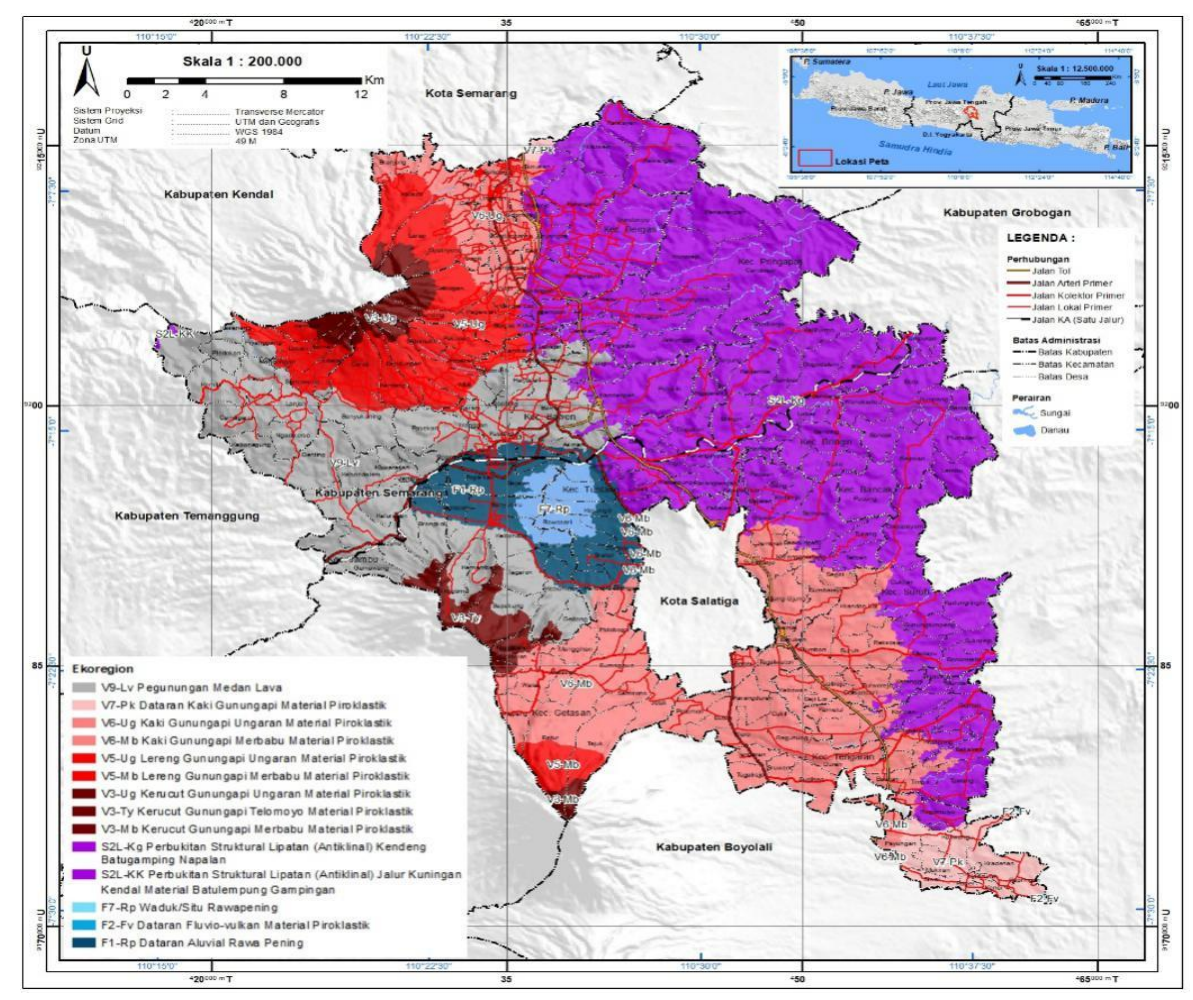

Gambar 1. Ekoregion Kabupaten Semarang (P3EJ, 2015)

Secara genesis suatu daerah terdiri dari beberapa proses pembentukannya, berdasarkan

kenampakan tersebut memiliki lingkungan yang berberda-beda potensi dengan 
pendekatan ekoregion yang dicirikan dengan lingkungan yang sama (Santosa, 2010; Muta'ali, 2015). Berdasarkan latar belakang tersebut, tujuan dari penelitian ini adalah untuk mengetahui daya dukung dan daya tampung lingkungan fisik pada sektor penyediaan, diantaranya adalah penyediaan lingkungan fisik untuk pangan atau kemampuan untuk sebagai lahan pertanian atau ketahanan pangan dan penyedia air tanah berbasis jasa ekosistem dengan pendekatan keruangan (spasial).

Sistem Informasi Geografi (SIG) dapat mendukung pengambilan keputusan secara keruangan (spaial) dengan informasi diintregasikan dengan karakteristik fenomena di suatu daerah (Santosa, 2010; Muta'ali, 2015; P3EJ, 2017). Analisis keruangan yang digunakan dalam mengolah data daya dukung dan daya tampung dapat dilakukan dengan teknik tumpang susun (overlay) parameter ekoregion dan penggunaan lahan. Kemudian dihitung dengan pendekatan pembobotan. Hasil dari analisis secara keruangan mempunyai kelebihan dibanding penyajian berupa visual angka, yaitu dapat menentukan lokasi-lokasi strategis dengan karakteristik tertentu dengan nilai jasa ekosistem yang bervasiasi, dapat diketahui sebaran distribusi nilai ekosistem secara batas administrasi maupun unit analisis lainya (ekoregion).

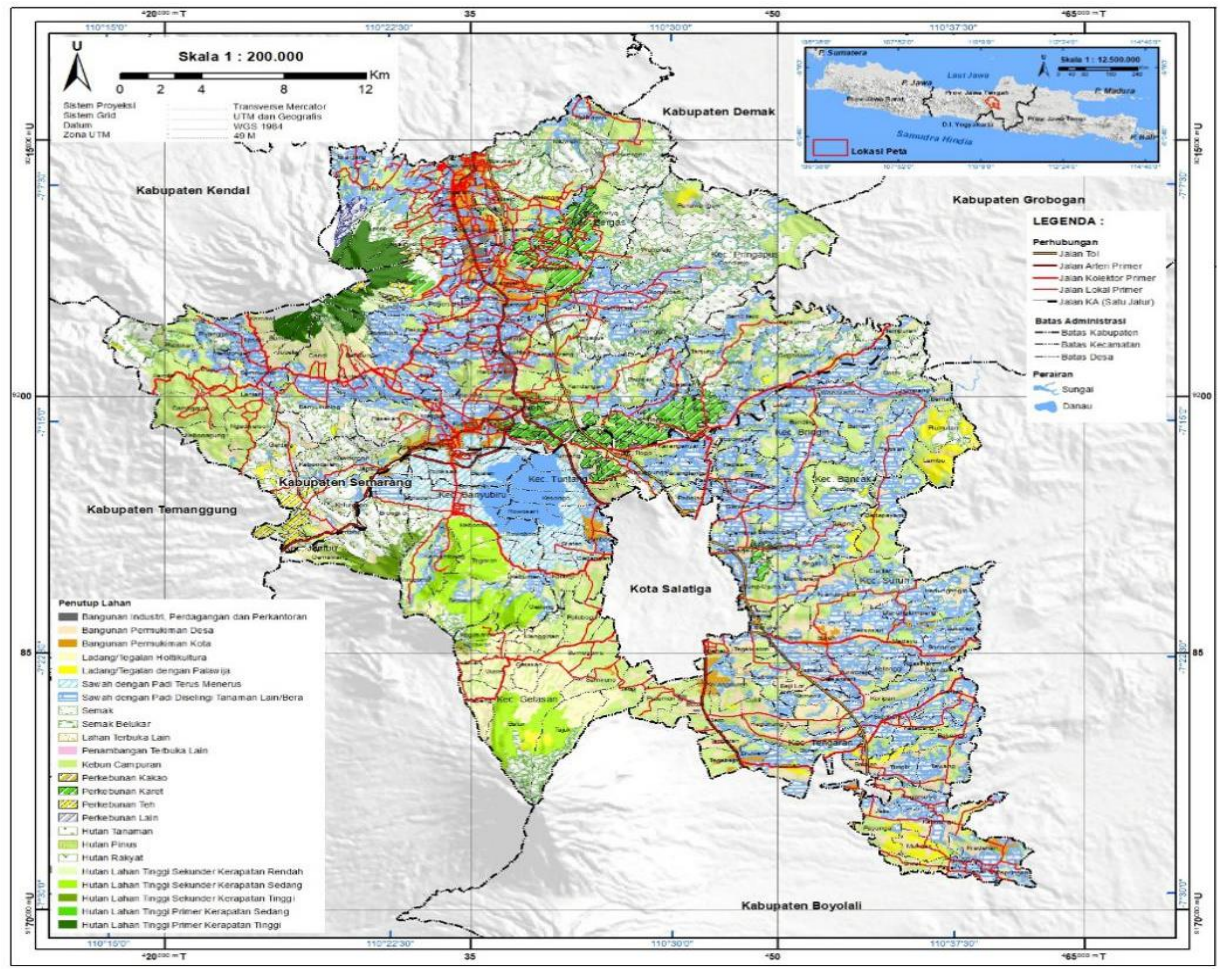

Gambar 2. Penggunaan Lahan Kabupaten Semarang

\section{Metode}

Kabupaten Semarang adalah salah satu kabupaten yang berada di Provinsi Jawa Tengah. Secara administratif letak geografis, Kabupaten Semarang berbatasan langsung dengan Kabupaten / Kota, sebagai berikut: sebelah barat Kabupaten Kendal dan Kabupaten Temanggung, sebelah selatan Kabupaten Boyolali, sebelah tmur Kabupaten Grobogan dan Kabupaten Demak, sebelah utara Kota Semarang, bagian tengah
Terletak Kota Salatiga dengan luas wilayah 950.207 km2 (BPS Kabupaten Semarang, 2019).

Data yang digunakan untuk mengolah daya dukung dan daya tampung antara lain; (a) ekoregion Kabupaten Semarang, yang diperoleh dari P3EJ tahun 2015, (b) data penggunaan lahan, yang diperoleh dari Badan Informasi Geografi (BIG) dan diperbaharui oleh Dinas Lingkungan Hidup (DLH) kabupaten Semarang pada tahun 2017. Tata cara perhitungan merujuk dari Pedoman Penentuan Daya Dukung dan Daya 
Tampung Lingkungan Hidup tahun 2014 (Kementerian Lingkungan Hidup, 2014). Tata cara analisis merujuk dari pedoman Panduan Penggunaan Data Spasial Daya Dukung dan Daya Tampung Lingkungan Hidup Berbasis Jasa Ekosistem di wilayah Ekoregion Jawa tahun 2017 (P3EJ, 2017)

\section{Penilaian Ekoregion dan Penutup Lahan}

Penilaian untuk menyusun daya dukung dan daya tampung berbasis jasa ekosistem menggunakan metode valuasi berbasis ahli dan referensi standar yaitu penilaian peran masingmasing jenis tipe penutup lahan dan ekoregion yang dilakukan oleh sejumlah ahli yang berkompeten di bidangnya, serta turut diperkuat dengan pertimbangan referensi standar terkait kondisi yang berbeda antara Kabupaten Semarang dengan daerah lain. Metode yang digunakan pada dasarnya mirip dengan penerapan metode Delphi. Secara garis besar merupakan suatu metode yang dilakukan dengan membentuk suatu kelompok atau komunikasi grup yang terdiri dari para ahli untuk membahas suatu permasalahan dari setiap kondisi lingkungan. Dari seluruh hasil peniaian dari para ahli, data tersebut diolah dengan analisis pairwise comparation, kemudian hasilnya dianalisis dengan SIG (P3EJ, 2017).

\section{Analisis Pairwise Comparation}

Analisis Pairwise Comparation merupakan pendekatan yang digunakan untuk memberikan nilai dari setiap kelas dari masing-masing paremeter. Nilai setiap parameter ditentukan dengan pendekatan expert judgment. Pendekatan expert judgment diperoleh dari sudut pandang para ahli untuk menentukan rentang nilai setiap parameter (Enrique dan Milagros, 2017). Berdasarkan nilai setiap kelas dari masing-masing parameter dibandingkan dengan, yaitu paremeter ekoregion dan penggunaan lahan dalam bentuk matrik.

Hasil dari perbandingan berpasangan dengan variabel satuan unit ekoregion dan penggunaan lahan akan menghasilkan nilai yang sesuai dengan karakeristik kemampuan lingkungan. Berdasarkan nilai tersebut, jika semakin tinggi nilai koefisien dari parameter ekoregion dan penutup lahan, berarti semakin penting peranan atau berpengaruh terhadap nilai jasa ekosistem (P3EJ, 2017).

\section{Koefisien Jasa Ekosistem (KJE)}

Nilai hasil perbandingan berpasangan dari hasil penilaian AHP (nilai ekoregion dan penutup lahan) tersebut disusun nilai koefisien jasa ekosistem dengan faktor perkalian sebagai berikut (P3EJ, 2017):

$\mathrm{KJE}=\mathrm{kec} \times \mathrm{klc}$

dimana:

$\mathrm{kec}=$ koefisien berdasarkan ekoregion

$\mathrm{klc}=$ koefisien berdasarkan penutup lahan

\section{Klasifikasi Nilai Koefisien Jasa Ekosistem (KJE)}

Nilai dari KJE dikelompokkan atau diklasifisikasikan kedalam setiap jasa ekosistem. Nilai rentang KJE dinormalisasi dengan pendekatan scalling dengan rentang nilai antara $0-1$. Nilai semakin mendekati nilai 1 , berarti KJE suatu wialayah semakin tinggi dan sebaliknya. Setiap nilai jasa ekosistem yang dihasilkan memiliki rentang nilai atau kelas yang berbedabeda, yang diperoleh dari perbedaan nilai maksimum dan minimum yang beragam. Berdasarkan pedoman penyusunan daya dukung dan daya tampung, nilai KJE dapat diklasifikasikan menjadi 5 tingkat, dengan pendekatan geometrik sebagai berikut (P3EJ, 2017):

$$
\begin{aligned}
& \mathrm{X} n=\mathrm{B} / \mathrm{A} \ldots \ldots \ldots . . . \\
& \text { dimana: } \\
& \mathrm{B}=\text { nilai maksimum } \\
& \mathrm{A}=\text { nilai minimum } \\
& \mathrm{n}=\text { jumlah kelas }
\end{aligned}
$$

\section{Indeks Jasa Ekosistem (IJE) dan Indek Komposit Jasa Ekosistem (IKJE)}

Nilai Indek Jasa Ekosistem IJE merupakan nilai indek besar kecil nilai dari jenis-jenis jasa ekosistem berkisar 0-1. IJE dihitung dengan pembobotan dengan satuan luas area (polygon) sebagai berikut (P3EJ, 2017):

$\mathrm{IJEi}, \mathrm{X}=$

$\underline{(K J E i, a \times L P a)+(K J E i, b \times L P b)+(K J E i, c \times L P c)+\cdots(K J E i, n \times L P n)}$

dimana: 
IJE $\mathrm{i}, \mathrm{x}=$ nilai indek jasa ekosistem jenis $\mathrm{i}$ (misal: pangan) di wilayah $x$ (misal: kabupaten/ekoregion)

KJE $\mathrm{i}, \mathrm{x}=$ koefisien jasa ekosistem jenis $\mathrm{i}$ (misal : pangan) di polygon a (misal: kabuapten)

$\mathrm{LPa}=$ luas polygon a dengan nilai $\mathrm{KJE}$ a

$\mathrm{LA}$ tot $=$ luas polygon total $(\mathrm{km} 2 / \mathrm{m} 2)$

Dalam menyajikan seluruh indek nilai jasa ekosistem, diperoleh dengan cara melakukan perhitungan rata-rata, sebagai berikut (P3EJ, 2017):

IKJE i, $\mathrm{x}=\frac{I J E i, x+I J E j, x+I J E k, x+I J E l, x+I J E m, x}{\sum I J E}$

dimana:

IKJE $\mathrm{i}, \mathrm{x}=$ nilai indek komposit jasa ekosistem kelompok jasa ekosistem i (misal: penyedia)

IJE $\mathrm{i}, \mathrm{x}=$ indek jasa ekosistem (misal:pangan, air bersih, bahan bakar)

$\sum \mathrm{IJE}=$ Jumlah jasa ekosistem (misal:

kelompok jasa pendukung $=5$ IJE)

Penentuan kelas daya dukung lingkungan diperoleh dari rentang nilai indek jasa ekosistem. Klasifikasi kelas daya dukung dan daya tampung diperoleh dengan pendekatan equal interval dengan jumlah kelas lima (5), yaitu sangat rendah, rendah, sedang, tinggi dan sangat tinggi. (DLH Kabupaten Semarang, 2018; P3EJ, 2017).

\section{Hasil dan pembahasan \\ Jasa Ekosistem Penyedia Pangan}

Kabupaten Semarang memiliki karakteristik lahan tersendiri, mengacu kepada ekoregion dan penutup lahan yang dimiliki. Masing-masing lahan memiliki ciri khas yang berbeda termasuk dalam penyediaan bahan pangan bagi manusia.

Berdasarkan hasil perhitungan daya dukung, secara garis besar di Kabupaten Semarang, lahan yang mampu menyediakan bahan pangan dapat dibagi menjadi lahan berpotensi sangat rendah, rendah, sedang, tinggi, dan sangat tinggi. Berdasarkan hasil pernitungan nilai indek jasa ekosistem penyediaan pangan dengan kelas sangat rendah hingga rendah dominan dijumpai di sebelah barat Kabupaten Semarang. Luasan tiap kecamatan dalam konteks penyediaan pangan dengan kelas sangat rendah rendah terdapat di Kecamatan Banyubiru, Kecamatan Bawen, dan Kecamatan Jambu. Luasan wilayah Kabupaten Semarang dengan kelas jasa penyediaan pangan sangat rendah - rendah adalah sebesar 28.265,62 $\mathrm{Ha}$ atau setara 27,87\% dari luas keseluruhan Kabupaten Semarang.

Berdasarkan hasil perhitungan nilai indek jasa ekosistem untuk penyediaan pangan dengan kelas sedang terdapat di bagian utara, disertai sebaran acak di bagian tengah hingga selatan wilayah Kabupaten Semarang. Distribusi luasan per kecamatan untuk penyediaan pangan dengan kelas sedang paling tinggi terdapat di Kecamatan Ungaran Timur, Kecamatan Bergas, Kecamatan Pringapus, Kecamatan Getasan, Kecamatan Suruh, Kecamatan Tengaran, dan Kecamatan Tuntang.Wilayah dengan jasa ekosistem penyediaan pangan kelas sedang memiliki luasan sebesar 19.458,48 Ha atau setara dengan persentase $19,12 \%$ dari luas keseluruhan Kabupaten Semarang.

Hasil dari perhitungan indeks, diketahui bahwa daya dukung lingkungan jasa ekosistem penyedia pangan dengan kelas tinggi - sangat tinggi di Kabupaten Semarang memiliki pola sebaran merata nyaris di seluruh luasan wilayah. Sebaran di tiap kecamatan untuk penyediaan pangan dengan kelas tinggi - sangat tinggi terdapat di Kecamatan Bringin, Kecamatan Suruh, Kecamatan Susukan, Kecamatan Tuntang, dan Kecamatan Ungaran Timur. Wilayah dengan jasa ekosistem penyediaan pangan kelas tinggi sangat tinggi memiliki luasan sebesar 53.952,39 $\mathrm{Ha}$ atau setara dengan persentase $53,01 \%$ dari luas keseluruhan Kabupaten Semarang. Informasi rinci mengenai luasan tiap kelas jasa ekosistem penyediaan pangan di Kabupaten Semarang disajikan dalam Tabel 1.

Pola sebasan spasial dari jasa ekosistem penyediaan pangan menghadirkan informasi tersendiri. Dominasi luasan dengan daya dukung lingkungan jasa penyediaan pangan di Kabupaten Semarang mengindikasikan adanya pengaruh kuat dari proes geomorfologi yakni proses vulkanik. Sebagian besar lahan yang memiliki kelas tinggi dalam jasa penyediaan pangan terletak pada Ekoregion Kaki Gunungapi, Lereng Kaki 
Gunungapi, Dataran Fluvio-vulkan. Ekoregion tersebut memiliki kesamaan utama yakni merupakan wilayah dengan topografi relatif datar dan terbentuk dari proses pengendapan fluvial. Hal tersebut dalam menunjukan hal yang serupa dalam penelitian Sabila (2020) bahwa pola sebaran dengan nilai yang tinggi di bentukan vulkanik juga dihasilkan pada perhitungan penyedia pangan.

Secara umum di Kabupaten Semarang didomniasi oleh hasil erupsi gunungapi. Dalam perkembangannya, material hasil erupsi gunungapi tersebut membentuk tanah dengan klasifikasi andosol dan aluvial. Kedua karakteristik tanah tersebut memiliki unsur hara tinggi atau memiliki kesuburan tinggi. Karakteristik tanah tersebut membuat penggunaan lahan dengan kesesuaian untuk pertanian dan perkebuanan yang produktif.

Ekoregion lain berupa perbukitan struktural yang juga dominan di wilayah Kabupaten Semarang ternyata dianggap masih cukup mampu menyediakan pangan, meski dengan keterbatasan aspek tanah, morfologi, dan air. Ekoregion dengan jasa penyediaan pangan terbilang rendah ada pada Ekoregion Pegunungan Medan Lava dan Kerucut Gunungapi dengan keterbatasan utama pada aspek morfologi, ketersediaan tanah dan air yang tergolong minim. Informasi spasial mengenai sebaran kelas jasa ekosistem penyedia pangan di Kabupaten Semarang disajikan pada Gambar 3.

\section{Jasa Ekosistem Penyediaan Air Bersih}

Jasa ekosistem penyediaan selain sektor pangan, dianalisis juga untuk penyedia air. Dari sudut pandang ekologi, air bersih juga merupakan salah satu manfaat yang dapat diperoleh dari fungsi ekosistem. Secara alami, air bersih dapat diperoleh dari air permukaan, seperti: sungai dan danau maupun berasal dari air tanah. Seperti halnya variasi secara spasial pada daya dukung jasa ekosistem penyediaan pangan, jasa ekosistem penyedia air bersih di Kabupaten Semarang juga memiliki karakteristik tersendiri, baik pada tingkatan buruk maupun pada tingkatan baik. Lingkungan Kabupaten Semarang mampu menyediakan air bersih dengan diferensiasi pada kelas sangat rendah rendah, sedang, tinggi, dan juga sangat tinggi.

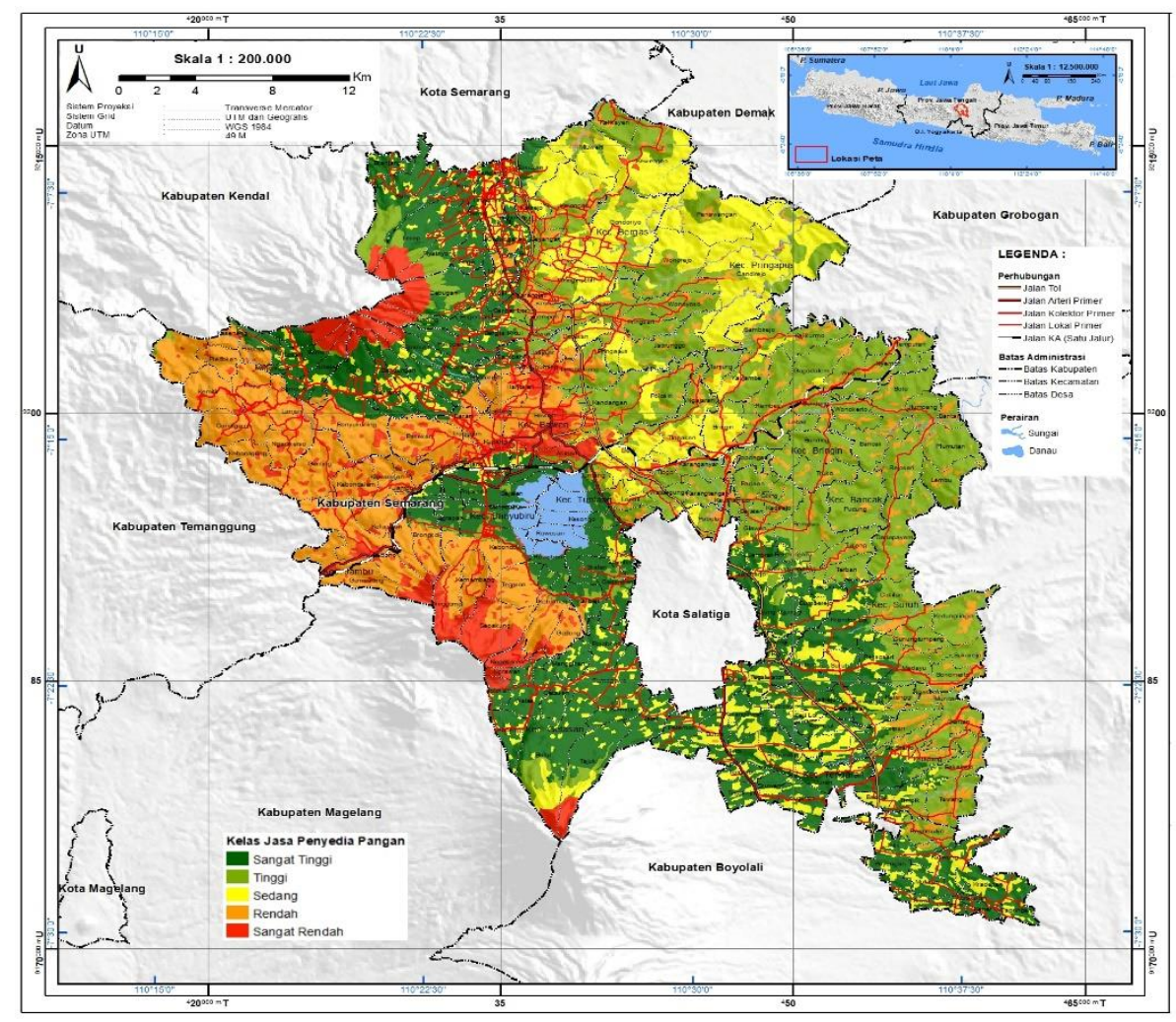

Gambar 3. Daya Dukung Daya Tampung Penyedia Pangan 
Tabel 1. Luas Tiap Kelas Jasa Ekosistem Penyedia Pangan Per Kecamatan di Kabupaten Semarang

\begin{tabular}{|c|c|c|c|c|c|c|c|c|c|c|c|c|c|}
\hline \multirow[t]{3}{*}{ No. } & \multirow[t]{3}{*}{ Kecamatan } & \multicolumn{10}{|c|}{ Kelas Koefisien Jasa Ekosistem Penyedia Pangan } & \multirow{2}{*}{\multicolumn{2}{|c|}{ Total }} \\
\hline & & \multicolumn{2}{|c|}{ Sangat Rendah } & \multicolumn{2}{|c|}{ Rendah } & \multicolumn{2}{|c|}{ Sedang } & \multicolumn{2}{|c|}{ Tinggi } & \multicolumn{2}{|c|}{ Sangat Tinggi } & & \\
\hline & & $\mathrm{Ha}$ & $\%$ & $\mathrm{Ha}$ & $\%$ & $\mathrm{Ha}$ & $\%$ & $\mathrm{Ha}$ & $\%$ & $\mathrm{Ha}$ & $\%$ & $\mathrm{Ha}$ & $\%$ \\
\hline 1 & Kec. Ambarawa & 575,11 & 0,57 & 1101,31 & 1,08 & 266,60 & 0,26 & 35,00 & 0,03 & 1051,39 & 1,03 & 3029,41 & 2,98 \\
\hline 2 & Kec. Bancak & 73,70 & 0,07 & 508,91 & 0,50 & 0 & 0,00 & 3935,56 & 3,87 & 0 & 0,00 & 4518,16 & 4,44 \\
\hline 3 & Kec. Bandungan & 488,88 & 0,48 & 826,99 & 0,81 & 697,70 & 0,69 & 10,39 & 0,01 & 2345,24 & 2,30 & 4369,21 & 4,29 \\
\hline 4 & Kec. Banyubiru & 1752,01 & 1,72 & 2286,25 & 2,25 & 0 & 0,00 & 298,76 & 0,29 & 948,97 & 0,93 & 5286,00 & 5,19 \\
\hline 5 & Kec. Bawen & 1067,93 & 1,05 & 1541,12 & 1,51 & 327,93 & 0,32 & 1705,35 & 1,68 & 213,20 & 0,21 & 4855,52 & 4,77 \\
\hline 6 & Kec. Bergas & 617,28 & 0,61 & 654,82 & 0,64 & 1716,98 & 1,69 & 1364,15 & 1,34 & 1178,09 & 1,16 & 5531,32 & 5,43 \\
\hline 7 & Kec. Bringin & 119,12 & 0,12 & 1094,43 & 1,08 & 791,11 & 0,78 & 5151,77 & 5,06 & 0 & 0,00 & 7156,43 & 7,03 \\
\hline 8 & Kec. Getasan & 632,81 & 0,62 & 36,48 & 0,04 & 1071,21 & 1,05 & 394,16 & 0,39 & 4398,91 & 4,32 & 6533,56 & 6,42 \\
\hline 9 & Kec. Jambu & 965,24 & 0,95 & 3987,91 & 3,92 & 60,15 & 0,06 & 43,61 & 0,04 & 312,08 & 0,31 & 5369,00 & 5,28 \\
\hline 10 & Kec. Kaliwungu & 7,71 & 0,01 & 91,49 & 0,09 & 949,39 & 0,93 & 273,80 & 0,27 & 1847,46 & 1,82 & 3169,85 & 3,11 \\
\hline 11 & Kec. Pabelan & 0,32 & 0,00 & 440,69 & 0,43 & 658,49 & 0,65 & 2697,90 & 2,65 & 1329,40 & 1,31 & 5126,81 & 5,04 \\
\hline 12 & Kec. Pringapus & 138,19 & 0,14 & 641,26 & 0,63 & 4354,66 & 4,28 & 3052,51 & 3,00 & 0 & 0,00 & 8186,62 & 8,04 \\
\hline 13 & Kec. Sumowono & 690,37 & 0,68 & 3922,74 & 3,85 & 183,54 & 0,18 & 69,85 & 0,07 & 979,87 & 0,96 & 5846,38 & 5,74 \\
\hline 14 & Kec. Suruh & 27,43 & 0,03 & 670,20 & 0,66 & 1176,00 & 1,16 & 3297,08 & 3,24 & 2275,84 & 2,24 & 7446,54 & 7,32 \\
\hline 15 & Kec. Susukan & 0 & 0,00 & 706,44 & 0,69 & 688,32 & 0,68 & 1951,61 & 1,92 & 1100,09 & 1,08 & 4446,46 & 4,37 \\
\hline 16 & Kec. Tengaran & 0 & 0,00 & 28,93 & 0,03 & 1641,69 & 1,61 & 3,59 & 0,00 & 2949,97 & 2,90 & 4624,19 & 4,54 \\
\hline 17 & Kec. Tuntang & 986,02 & 0,97 & 640,87 & 0,63 & 1294,62 & 1,27 & 1890,63 & 1,86 & 1445,77 & 1,42 & 6257,90 & 6,15 \\
\hline 18 & Kec. Ungaran Barat & 418,72 & 0,41 & 34,43 & 0,03 & 876,29 & 0,86 & 620,22 & 0,61 & 2581,58 & 2,54 & 4531,24 & 4,45 \\
\hline 19 & Kec. Ungaran Timur & 59,96 & 0,06 & 529,36 & 0,52 & 2703,82 & 2,66 & 1663,56 & 1,63 & 534,98 & 0,53 & 5491,68 & 5,40 \\
\hline Total & & 8620,79 & 8,47 & 19744,62 & 19,40 & 19458,48 & 19,12 & 28459,54 & 27,96 & 25492,85 & 25,05 & 101776,30 & 100,00 \\
\hline
\end{tabular}

Sumber: Perhitungan, 2020 
Jasa Ekosistem Penyediaan Air Bersih dengan kelas sangat rendah hingga rendah dominan dijumpai di sebelah barat Kabupaten Semarang. Luasan tiap kecamatan dalam konteks penyediaan air bersih dengan kelas sangat rendah - rendah terdapat di Kecamatan Ambarawa, Kecamatan Banyubiru Kecamatan Bawen, Kecamatan Jambu, dan Kecamatan Sumowono. Luasan wilayah Kabupaten Semarang dengan kelas jasa penyediaan pangan sangat rendah rendah adalah sebesar $26.370,26 \mathrm{Ha}$ atau setara 25,91\% dari luas keseluruhan Kabupaten Semarang.

Penyediaan air bersih dengan kelas sedang terdapat di bagian tengah hingga ke batas antara ekoregion terpengaruh proses vulkanik dengan komplek ekoregion perbukitan struktural di sebelah timur dari Kabupaten Semarang. Distribusi luasan per kecamatan untuk penyediaan air bersih dengan kelas sedang paling tinggi terdapat di Kecamatan Ungaran Timur, Kecamatan Bergas, Kecamatan Pringapus, Kecamatan Getasan, Kecamatan Suruh, Kecamatan Tengaran, dan Kecamatan Tuntang. Wilayah dengan jasa ekosistem penyediaan air bersih kelas sedang memiliki luasan sebesar $19.458,48 \mathrm{Ha}$ atau setara dengan persentase $27,01 \%$ dari luas keseluruhan Kabupaten Semarang.

Daya dukung lingkungan jasa ekosistem penyedia air bersih dengan kelas tinggi - sangat tinggi di Kabupaten Semarang memiliki pola sebaran keruangan dominan di sekitar komplek ekoregion gunungapi, terutama ekoreion lereng gunungapi dan kaki gunungapi. Widodo, Lupyanto, Sulistiono, Harjito \& hamidin (2015) menyebutkan karakteristik kelas tinggi dengan bentuk lahan adal gunung api. Bagian timur dari komplek ekoregion perukitan struktural juga memiliki potensi penyediaan air bersih.

Di sekitar Waduk Rawa Pening pun diketahui memiliki jasa penyediaan air bersih dengan kelas tinggi - sangat tinggi. Sebaran per kecamatan dari jasa ekosistem penyediaan air bersih terdapat di Kecamatan Getasan, Kecamatan Pringapus, dan Kecamatan tengaran. Wilayah dengan jasa ekosistem penyediaan air bersih kelas tinggi - sangat tinggi memiliki luasan sebesar $47921,19 \mathrm{Ha}$ atau setara dengan persentase $47,09 \%$ dari luas keseluruhan Kabupaten Semarang. Informasi rinci mengenai luasan tiap kelas jasa ekosistem penyediaan air bersih di Kabupaten Semarang disajikan dalam Tabel 2.
Sebagian besar wilayah yang memiliki potensi tinggi dalam penyediaan air bersih terletak pada ekoregion Lereng Gunungapi, Kaki Gunungapi, Dataran Aluvial, Dataran Fluviovulkan, dan Tubuh Air Waduk Rawa Pening. Komplek Ekoregion yang kuat dipengaruhi oleh proses vulkanik mayoritas tersusun oleh material aluvium yang mampu membentuk akuifer yang potensial, dengan dukungan morfologi yang datar. Kondisi seperti ini menyebabkan cadangan atau ketersediaan air tanahnya relatif dangkal (< $10 \mathrm{~m}$ ) yang membentuk reservoir air tanah atau cekungan hidrogeologi.

Komplek ekoregion dengan asal proses vulkanik pun umumya juga memiliki sungai yang mengalir sepanjang tahun. Wilayah dengan keas rendah untuk jasa penyediaan air bersih terletak pada Ekoregion Kerucut Gunungapi dan Perbukitan Medan Lava. Faktor pembatas utama ekoregion tersebut dalam konteks penyediaan air bersih adalah faktor morfologi yang mereduksi kemungkinan keberadaan potensi aliran permukaan guna dimanfaatkan air bersihnya, serta faktor material bawah permukaan yang terbilang masif dan tidak mampu menyimpan maupun melalukan air tanah dalam jumlah yang cukup. Informasi distribusi keruangan mengenai sebaran kelas jasa ekosistem penyedia air bersih di Kabupaten Semarang disajikan pada Gambar 4.

Hasil dari daya dukung dan daya tampung berbasis jasa ekosistem untuk air bersih mempunyai potensi dikembangan pada satuan unit tinggi hingga sangat tinggi. Kondisi tersebut juga berkorelasi dengan kondisi geologi dan ekoregion dimana potensi air tinggi pada daerah lereng bawah dengan karakteristik merupakan tekuk lereng hingga lereng kaki dengan potensi air berada di material primer yaitu pasiran dengan ketebalan yang tinggi (Kecamatan Getasan Tengaran Bergas Tuntang). Sedangkan potensi rendah merupakan daerah perbukitan perlipatan dengan potensi material lempungan yang relaif terbatas secara produktivitas. Kondisi tersebut juga mempunyai informasi yang sama bila dilihat dari peta cekungan air tanah (Permen ESDM no. 2 tahun 2012 tentang cekungan air tanah) dimana terdapat daerah non cekungan air tanah (nonCAT) dianataranya Kecamatan Pringapus dan Bancak. 


\begin{tabular}{|c|c|c|c|c|c|c|c|c|c|c|c|c|c|}
\hline \multirow[t]{3}{*}{ No. } & \multirow[t]{3}{*}{ Kecamatan } & \multicolumn{10}{|c|}{ Kelas Koefisien Jasa Ekosistem Penyedia Air Bersih } & \multirow{2}{*}{\multicolumn{2}{|c|}{ Total }} \\
\hline & & \multicolumn{2}{|c|}{ Sangat Rendah } & \multicolumn{2}{|l|}{ Rendah } & \multicolumn{2}{|l|}{ Sedang } & \multicolumn{2}{|l|}{ Tinggi } & \multicolumn{2}{|c|}{ Sangat Tinggi } & & \\
\hline & & $\mathrm{Ha}$ & $\%$ & $\mathrm{Ha}$ & $\%$ & $\mathrm{Ha}$ & $\%$ & $\mathrm{Ha}$ & $\%$ & $\mathrm{Ha}$ & $\%$ & $\mathrm{Ha}$ & $\%$ \\
\hline 1 & Kec. Ambarawa & 1495,43 & 1,47 & 0 & 0,00 & 9,41 & 0,01 & 335,73 & 0,33 & 1188,84 & 1,17 & 3029,41 & 2,98 \\
\hline 2 & Kec. Bancak & 0 & 0,00 & 508,91 & 0,50 & 3122,14 & 3,07 & 887,12 & 0,87 & 0 & 0,00 & 4518,16 & 4,44 \\
\hline 3 & Kec. Bandungan & 1315,87 & 1,29 & 0 & 0,00 & 650,55 & 0,64 & 2392,40 & 2,35 & 10,39 & 0,01 & 4369,21 & 4,29 \\
\hline 4 & Kec. Banyubiru & 3647,76 & 3,58 & 0 & 0,00 & 0 & 0,00 & 299,89 & 0,29 & 1338,35 & 1,31 & 5286,00 & 5,19 \\
\hline 5 & Kec. Bawen & 2378,07 & 2,34 & 226,36 & 0,22 & 1455,25 & 1,43 & 788,64 & 0,77 & 7,19 & 0,01 & 4855,52 & 4,77 \\
\hline 6 & Kec. Bergas & 758,87 & 0,75 & 528,71 & 0,52 & 2255,56 & 2,22 & 1508,23 & 1,48 & 479,95 & 0,47 & 5531,32 & 5,43 \\
\hline 7 & Kec. Bringin & 0 & 0,00 & 1094,43 & 1,08 & 4302,13 & 4,23 & 1759,87 & 1,73 & 0 & 0,00 & 7156,43 & 7,03 \\
\hline 8 & Kec. Getasan & 666,87 & 0,66 & 0 & 0,00 & 35,93 & 0,04 & 4836,02 & 4,75 & 994,75 & 0,98 & 6533,56 & 6,42 \\
\hline 9 & Kec. Jambu & 4953,15 & 4,87 & 0 & 0,00 & 0 & 0,00 & 103,77 & 0,10 & 312,08 & 0,31 & 5369,00 & 5,28 \\
\hline 10 & Kec. Kaliwungu & 0 & 0,00 & 91,49 & 0,09 & 382,16 & 0,38 & 1818,71 & 1,79 & 877,49 & 0,86 & 3169,85 & 3,11 \\
\hline 11 & Kec. Pabelan & 0 & 0,00 & 440,69 & 0,43 & 2508,08 & 2,46 & 1439,76 & 1,41 & 738,28 & 0,73 & 5126,81 & 5,04 \\
\hline 12 & Kec. Pringapus & 53,04 & 0,05 & 591,72 & 0,58 & 2223,76 & 2,18 & 5318,10 & 5,23 & 0 & 0,00 & 8186,62 & 8,04 \\
\hline 13 & Kec. Sumowono & 4613,11 & 4,53 & 0 & 0,00 & 183,54 & 0,18 & 1015,26 & 1,00 & 34,46 & 0,03 & 5846,38 & 5,74 \\
\hline 14 & Kec. Suruh & 0 & 0,00 & 671,20 & 0,66 & 2988,55 & 2,94 & 2425,90 & 2,38 & 1360,90 & 1,34 & 7446,54 & 7,32 \\
\hline 15 & Kec. Susukan & 0 & 0,00 & 706,44 & 0,69 & 1951,61 & 1,92 & 1195,71 & 1,17 & 592,70 & 0,58 & 4446,46 & 4,37 \\
\hline 16 & Kec. Tengaran & 0 & 0,00 & 26,32 & 0,03 & 280,51 & 0,28 & 3491,60 & 3,43 & 825,76 & 0,81 & 4624,19 & 4,54 \\
\hline 17 & Kec. Tuntang & 62,66 & 0,06 & 614,48 & 0,60 & 2490,48 & 2,45 & 926,79 & 0,91 & 2163,50 & 2,13 & 6257,90 & 6,15 \\
\hline 18 & Kec. Ungaran Barat & 418,72 & 0,41 & 0,02 & 0,00 & 594,41 & 0,58 & 1335,32 & 1,31 & 2182,77 & 2,14 & 4531,24 & 4,45 \\
\hline 19 & Kec. Ungaran Timur & 12,22 & 0,01 & 493,71 & 0,49 & 2050,79 & 2,01 & 2510,35 & 2,47 & 424,61 & 0,42 & 5491,68 & 5,40 \\
\hline Total & & 20375,77 & 20,02 & 5994,49 & 5,89 & 27484,85 & 27,01 & 34389,16 & 33,79 & 13532,03 & 13,30 & 101776,30 & 100,00 \\
\hline
\end{tabular}

Sumber : Perhitungan, 2020 


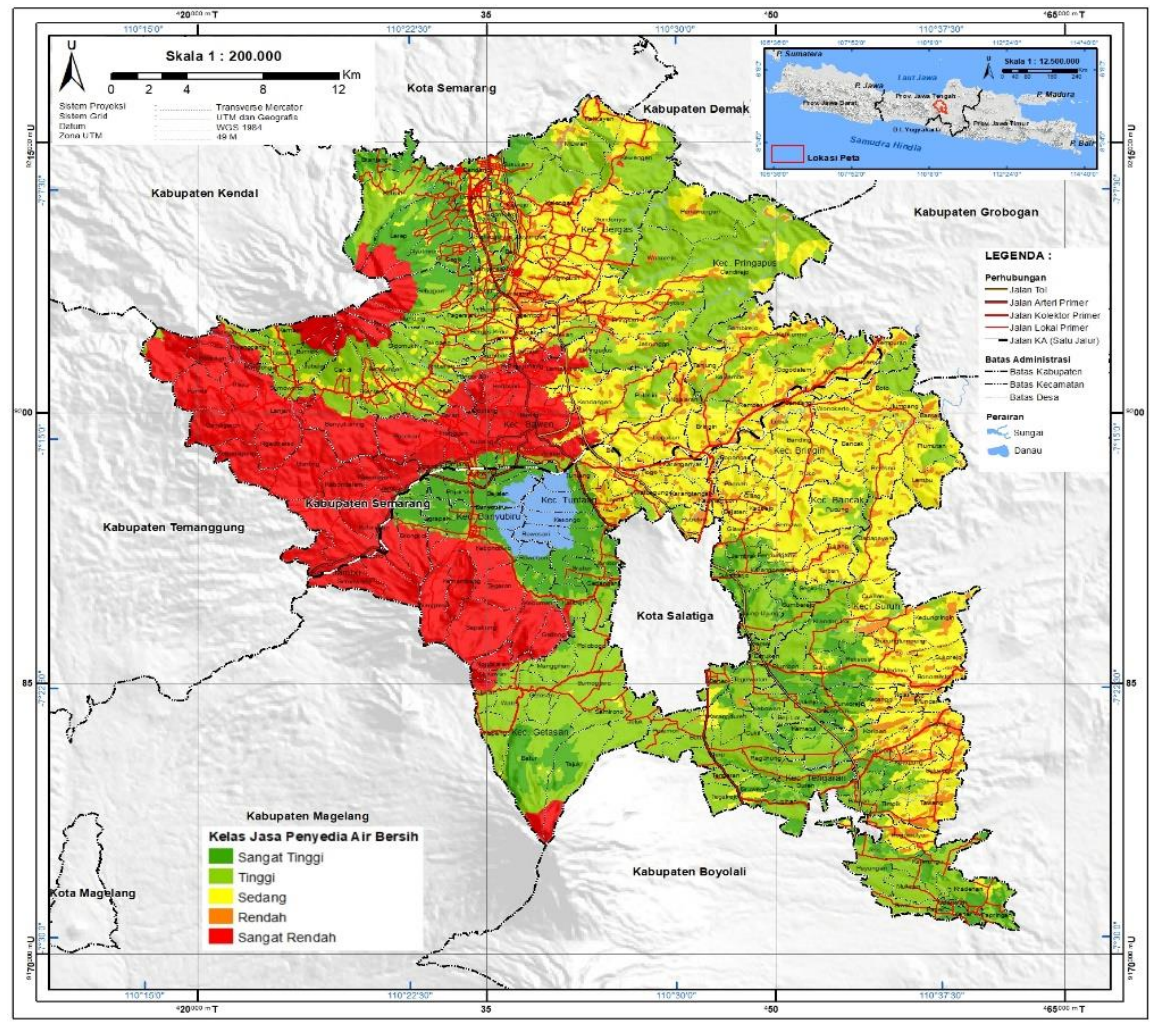

Gambar 4. Daya Dukung Daya Tampung Penyedia Air Bersih

\section{Simpulan}

Di Kabupaten Semarang daya dukung daya tampung untuk dari kapasitas penyedia menunjukkan nilai tinggi dengan ciri lingkungan daerahnya relatif datar untuk ditanami, berada dekat dengan material penyusun tanah dominasi pasiran. Jasa Ekosistem Penyediaan untuk air bersih dicirkan dengan ciri lingkungan berada di tekuk lereng atau lereng kaki dengan material akuifer pasiran (vulkanik). Sedangkan nilai rendah berada di bagian timur Kabupaten Semarang, yang terdiri dari perlipatan dengan material penyusun lempungan dimana karakteristik tersebut terbatas secara produktivitas air dan produktivitas sedang untuk ditanami untuk persawahan.

Jasa Ekosistem Penyediaan untuk pangan dan air bersih berada pada wilayah Ekoregion Lereng, Lereng Kaki Gunungapi, Dataran Aluvial, dan Dataran Fluvio-vulkan. Ekoregion Tubuh Air Waduk Rawa Pening dan sekitarnya juga mampu menyediakan jasa penyediaan yang baik. Kecamatan dengan jasa ekosistem penyediaan dengan kelas tinggi terdapat di Kecamatan Ungaran Barat, Kecamatan Bergas, Kecamatan Bandungan, Kecamatan Ambarawa, Kecamatan
Banyubiru, dan Kecamatan Tuntang. terima kasih disampaikan kepada berbagai pihak yang telah membantu dalam penelitian/penyusunan artikel. Dapat disampaikan kepada pemberi dana atau memberikan bantuan dan saran. Ucapan terima kasih digunakan untuk memberikan apresiasi kepada pihak-pihak yang berperan dalam penelitian/artikel. Apabila penelitian menggunakan dana DIPA atau hibah dari Kemenristekdikti, tuliskan nomor kontrak penelitiannya.

\section{Ucapan terima kasih}

Ucapan terima kasih disampaikan kepada Dinas Lingkungan Hidup Pemerintah Kabupaten Semarang yang telah memfasilitasi penelitian ini.

\section{Referensi}

BPS Kabupaten Semarang. (2019). Kabupaten Semarang Dalam Angka Tahun 2019. Pemerintah Kabupaten Semarang.

DLH Kabupaten Semarang. (2018). Daya Dukung Daya Tampung Kabupaten Semarang. Laporan Penelitian

Enrique M., and Milagros P.R. (2017). Practical Decision Making: An Introduction to the 
Analytic Hierarchy Process (AHP) Using Super Decisions V2 [1 ed.].SpringerBriefs in Operations Research.Springer International Publishing.

Kementerian Lingkungan Hidup. (2014). Pedoman Daya Dukung Daya Tampung Lingkungan. Jakarta :Kementerian Lingkungan Hidup Deputi 1 Bidang Tata Lingkungan Asisten Deputi Perencanaan Pemanfaatan SDA \& LH \& Kajian Kebijakan LH Wilayah \& Sektor Millennium Ecosystem Assessment (MEA). (2005). Ecosystems and Human Well- Being: Synthesis, Island Press, Washington, USA

Muta'ali L., 2015. Teknik Analisis Regional Untuk. Perencanaan Wilayah Tata Ruang dan Lingkungan. Yogyakarta: Badan Penerbit Fakultas Geografi.

Pusat Pengendalian Pembangunan Ekoregion Jawa, (2015). Peta Ekoregion Jawa Tengah. P3EJ. Yogyakarta

Pusat Pengendalian Pembangunan Ekoregion Jawa. (2017). Pedoman Penggunaan Peta Daya Dukung Dan Daya Tampung Lingkungan Hidup (D3TLH). P3EJ. Yogyakarta

Pusat Pengendalian Pembangunan Ekoregion Sumatera. (2011). Daya Dukung Dan Daya Tampung Lingkungan Hidup Ekoregion Sumatera Berbasis Jasa Ekosistem. P3ES. Pekanbaru

Republik Indonesia. (2009). Undang-Undang Republik Indonesia Nomor 32 Tahun 2009 tentang Perlindungan dan Pengelolaan Lingkungan Hidup. Lembaran Negara RI Tahun 2009 Nomor 140. Sekretariat Negara. Jakarta.

Sabila S. (2020). Daya Dukung Pangan Dalam Mendukung Ketersediaan Pangan Provinsi Sumatera Selatan. Jurnal Tanah dan Sumberdaya Lahan. Vol 7 No.1:59-68,2020.

Santosa L. W. (2010). Ekoregion sebagai Kerangka Dasar dalam Perlindungan dan Pengelolaan Lingkungan. Makalah. Disampaikan dalam seminara Nasional "Semangat Pejuangan dari Jogja: Kembalikan Indonesiaku Hijau". University Center UGM, 23 Desember 2010.

Sumadyanti U.V., Zuharnen, Widayani P. (2016). Monitoring Daya Dukung Lingkungan Berbasis Jasa Ekosistem (Rekreasi dan Ecotourism) Tahun 2000 dan 2015
Menggunakan Citra Landsat (Lokasi Kabupaten Badung Bagian Barat, Provinsi Bali). Jurnal Bumi Indonesia.Vol 5 No.4:1-10, 2016

Widodo, B., Lupyanto, R., Sulistiono, B., Harjito, D.A. dan Hamidin, J. (2015). Analysis of environmental carrying capacity for the development of sustainable settlement in Yogyakarta Urban Area. Procedia Environmental Sciences 28: 519-527. doi :10.1016/j.proenv.2015.07.062. 
Lampiran 1. Rekapitulasi Pairwise Pengaruh Ekoregion Terhadap Penyedia Pangan

\begin{tabular}{|c|c|c|c|c|c|c|c|}
\hline No & Kode & Penutup Lahan & $\begin{array}{l}\text { Penilaian } \\
\quad 1\end{array}$ & $\begin{array}{l}\text { Penilaian } \\
\quad 2\end{array}$ & $\begin{array}{l}\text { Penilaian } \\
\quad 3\end{array}$ & $\begin{array}{c}\text { Rata- } \\
\text { rata }\end{array}$ & $\begin{array}{l}\text { Nilai } \\
\text { Indek } \\
\text { Jasa }\end{array}$ \\
\hline 1 & 1 & Kerucut Gunungapi Ungaran Material Piroklastik & 0 & 0 & 0 & 0 & 0 \\
\hline 2 & 2 & Lereng Gunungapi Ungaran Material Piroklastik & 7 & 2 & 5 & 4.667 & 1.054 \\
\hline 3 & 3 & Kaki Gunungapi Ungaran Material Piroklastik & 8 & 6 & 9 & 7.667 & 1.731 \\
\hline 4 & 4 & Kerucut Gunungapi Merbabu Material Piroklastik & 0 & 0 & 0 & 0 & 0 \\
\hline 5 & 5 & Lereng Gunungapi Merbabu Material Piroklastik & 7 & 2 & 5 & 4.667 & 1.054 \\
\hline 6 & 6 & Kaki Gunungapi Merbabu Material Piroklastik & 8 & 6 & 9 & 7.667 & 1.731 \\
\hline 7 & 7 & Kerucut Gunungapi Telomoyo Material Piroklastik & 0 & 0 & 0 & 0 & 0 \\
\hline 8 & 8 & Dataran Kaki Gunungapi Material Piroklastik & 9 & 7 & 9 & 8.333 & 1.882 \\
\hline 9 & 9 & Pegunungan Medan Lava & 1 & 0 & 0 & 0.333 & 0.075 \\
\hline 10 & 10 & $\begin{array}{l}\text { Perbukitan Struktural Lipatan (Antiklinal) } \\
\text { Kendeng Batugamping Napalan }\end{array}$ & 2 & 1 & 2 & 1.667 & 0.376 \\
\hline 11 & 11 & $\begin{array}{l}\text { Perbukitan Struktural Lipatan (Antiklinal) Jalur } \\
\text { Kuningan-Kendal Material Batulempung } \\
\text { Gampingan }\end{array}$ & 1 & 1 & 3 & 1.667 & 0.376 \\
\hline 12 & 12 & Dataran Fluvio-vulkan Material Piroklastik & 9 & 7 & 9 & 8.333 & 1.882 \\
\hline 13 & 13 & Dataran Aluvial Rawa Pening & 9 & 8 & 9 & 8.667 & 1.957 \\
\hline 14 & 14 & Waduk/Situ Rawapening & 8 & 8 & 9 & 8.333 & 1.882 \\
\hline
\end{tabular}

Lampiran 2. Rekapitulasi Pairwise Pengaruh Ekoregion Terhadap Penyedia Pangan

\begin{tabular}{|c|c|c|c|c|c|c|c|}
\hline No & Kode & Penutup Lahan & $\begin{array}{c}\text { Penilaian } \\
1\end{array}$ & $\begin{array}{c}\text { Penilaian } \\
2\end{array}$ & $\begin{array}{c}\text { Penilaian } \\
3\end{array}$ & $\begin{array}{l}\text { Rata- } \\
\text { rata }\end{array}$ & $\begin{array}{c}\text { Nilai Indek } \\
\text { Jasa }\end{array}$ \\
\hline 1 & A & Industri, Perdagangan, Perkantoran & 1 & 0 & 0 & 0.333 & 0.073 \\
\hline 2 & B & Bangunan Pemukiman Desa & 3 & 0 & 1 & 1.333 & 0.29 \\
\hline 3 & $\mathrm{C}$ & Bangunan Pemukiman Kota & 2 & 0 & 1 & 1 & 0.218 \\
\hline 4 & $\mathrm{D}$ & Penambangan Terbuka Lain & 0 & 1 & 0 & 0.333 & 0.073 \\
\hline 5 & $\mathrm{E}$ & Lahan Terbuka Lain & 1 & 7 & 7 & 5 & 1.089 \\
\hline 6 & $\mathrm{~F}$ & Sawah Padi Terus Menerus & 9 & 9 & 9 & 9 & 1.96 \\
\hline 7 & G & Sawah Padi - Bera & 8 & 8 & 8 & 8 & 1.743 \\
\hline 8 & $\mathrm{H}$ & Ladang/Tegalan Holtikultura & 7 & 8 & 6 & 7 & 1.525 \\
\hline 9 & I & Ladang/Tegalan Palawija & 6 & 9 & 6 & 7 & 1.525 \\
\hline 10 & $\mathrm{~J}$ & $\begin{array}{l}\text { Tanaman Semusim Lahan Kering } \\
\text { Lain }\end{array}$ & 5 & 6 & 7 & 6 & 1.307 \\
\hline 11 & K & Kebun Campuran & 8 & 7 & 6 & 7 & 1.525 \\
\hline 12 & $\mathrm{~L}$ & Perkebunan Teh & 6 & 8 & 7 & 7 & 1.525 \\
\hline 13 & M & Perkebunan Karet & 0 & 4 & 5 & 3 & 0.653 \\
\hline 14 & $\mathrm{~N}$ & Perkebunan Lain & 7 & 4 & 8 & 6.333 & 1.38 \\
\hline 15 & $\mathrm{O}$ & Semak & 4 & 3 & 5 & 4 & 0.871 \\
\hline 16 & $\mathrm{P}$ & Semak Belukar & 1 & 2 & 3 & 2 & 0.436 \\
\hline 17 & Q & Hutan Tanaman & 6 & 6 & 8 & 6.667 & 1.452 \\
\hline 18 & $\mathrm{R}$ & Hutan Rakyat & 7 & 6 & 8 & 7 & 1.525 \\
\hline 19 & $S$ & Hutan Pinus & 2 & 3 & 5 & 3.333 & 0.726 \\
\hline 20 & $\mathrm{~T}$ & Hutan Lahan Tinggi Primer & 5 & 6 & 6 & 5.667 & 1.234 \\
\hline 21 & $\mathrm{U}$ & Hutan Lahan Tinggi Sekunder & 4 & 4 & 4 & 4 & 0.871 \\
\hline 22 & $\mathrm{~V}$ & Tubuh Air & 0 & 0 & 0 & 0 & 0 \\
\hline
\end{tabular}

Sumber : Analisis, 2020 